\title{
Dairy Value Chain Upgrading in Bishoftu Town, East Shewa, Oromia, Ethiopia
}

\author{
Gudeta Shanko Fikadu Mitiku $(\mathrm{PhD})$ Tura Kaso \\ Department of Agribusiness and Value Chain Management, Ambo University, Ambo, Ethiopia
}

\begin{abstract}
Despite tremendous potential for dairy production in Ethiopia, the sector is not upgraded generally in the country and specifically in Bishoftu town. Dairy value chain upgrading was analyzed with objectives of identifying actors in dairy value chain upgrading and measuring their performances. Data were collected in the town at dairy producers' level, traders (retailers) level and expert level through structured questionnaire and key informant interviews. Censuses of 141 dairy producers were conducted by dividing them into three different scale farm producers. Accordingly producers who have 1-5 dairy cows were categorized as small scale producers, 6-10 medium scale producers and $>11$ dairy cows were taken as large scale dairy farms. Based on this classification there were 100, 34, and 7 small, medium and large scale dairy respectively in the town. It was assumed that all large scale were processors, but one producer was found to be non-processor and was omitted from census survey. So, the survey was conducted with 140 dairy producers in the town. Data were analyzed by value chain analysis. The results from the descriptive statistics shows that from total dairy producers $46 \%$ were processing dairy /milk into yogurt, cheese and butter. Twenty four percent of the producers convert milk into yogurt, $11 \%$ process into cheese and butter, and another $11 \%$ process dairy into yogurt, cheese and butter. Therefore, producers' socioeconomic factors and institutional factors needed to be strengthened by supportive activities like training for capacity building of producers in order to upgrade dairy value chain in town.
\end{abstract}

Keywords: Upgrading, Value chain, performances, Dairy, Bishoftu town

DOI: $10.7176 / \mathrm{FSQM} / 103-01$

Publication date: December $31^{\text {st }} 2020$

\section{INTRODUCTION}

\section{Background of the study}

Value chain approach to livestock production is important to identify constraints and opportunities for upgrading strategy of the sector and to compete with the world in rapid globalization era (Jonathan, et al., 2009). It can provide the way to understand the need, scope of competitiveness and insights debates on how the poor should participate in global economy (Rich, et al., 2010).

The dairy value chain comprise about 500,000 smallholder rural farmers who produce about 1,130 million liters of milk of which 370 million liters of raw milk, 280 million liters of butter with cheese together, and 165 million liters is consumed by the calves. The remaining 315 million litres was marketed through both informal and formal retailers through farmers"e organizations (Mohammed, et al., 2009). Sustainable dairy value chain development approach and dairy value adding activities are important in Ethiopia. Because, dairy producerse could not get fair share from milk value through sustainable milk producing and marketing (Girma and Marco, 2013).

The commercial transformation of dairying is also considered as an important pathway for the development of dairy chain (World Bank, 2008), for reinforcing economic growth and macroeconomic development, and to support household food security and welfare (Pingali and Timmer, 1997). However, dairy value chain face shortage in the supply of dairy and its product because of informal marketing channels (Girma, 2012). There is reduction in volume of dairy produced by dairy producers"e on one hand due to low availability and high cost of animalse feeds and on the other hand high bargaining power of private milk collectors, weak relationship of dairy cooperative and its members are major factors affecting milk value chain in Bishoftu town (Girma and Marco, 2013). Therefore this study intended to identify the actors in the dairy value chain and measure their performances in the study area.

\section{LITERATURE}

Definitions and Basic Concepts of Value Chain Dairy: Dairy is the other name of cow's milk. Whereas dairy cow is the cow reared to produce cow milk.

Value chain: is the sequence of activities required to make a product or provide a service. Value chain included actors like; producers (farmers), collectors, traders (retailers, supermarkets, cafés and restaurants), processors and consumers (Gereffi and Luo, 2014). Value chain is a high-level model developed by Porter (1990) used to describe the process by which businesses receive raw materials, add value to the raw materials through various processes to create a finished product, and then sell that end product to customers. Companies conduct valuechain analysis by looking at every production step required to create a product and identifying ways to increase 
the efficiency of the chain. The overall goal is to deliver maximum value for the least possible total cost and create a competitive advantage. Porter (1990) also categorizes value chain into two activities. These are;

1. Primary Activities of the Value Chain: primary activities are essential in adding value and creating a competitive advantage. The first activity in the value chain is inbound logistics, which includes all receiving, warehousing and inventory management of raw materials ready for production. The second activity is operations and encompasses all efforts needed to convert raw materials into a finished product or service. Outbound logistics is the third activity in the value chain and occurs after all operations are completed and the end product is ready for the customer. Activities required to deliver a product to the end user are considered part of outbound logistics. Marketing and sales are the fourth part of the value chain and include all strategies used to get potential customers to purchase a product, such as channel selection, 8 advertising and pricing. Service is the fifth and final step in a company's value chain and describes all activities that create better consumer experiences, such as customer service and repair services (porter, 1990).

2. Support Activities of the Value Chain: Support activities facilitate the efficiency of the primary activities in a value chain. The four support activities are procurement, technological development, human resource management and company infrastructure. Increasing the efficiency of any of the four support activities increases the benefit to at least one of the five primary activities.

Value chain analysis: examines the full range of activities required to bring a product or service from its conception to its end use, actors that perform those activities in a vertical chain and final consumers for the product or service (Kaplinsky and Morris, 2003). Upgrading: Refers to the acquisition of technological capabilities and market linkages that enable firms to improve their competitiveness and move into highervalue activities. Upgrading in firms can take place in the form of process upgrading, product upgrading, functional upgrading and chain upgrading. Upgrading entails not only improvements in products, but also investments in people, knowhow, processes, equipment and favorable work conditions (Kaplinsky and Morris, 2003).

Value chain upgrading: different authors define upgrading in value chain differently. Gereffi and Luo (2014) define upgrading as: "a process of improving the ability of a firm or an economy to move to more profitable and/or technologically sophisticated capital and skill-intensive economic niches." McCullough et al. (2008) define the following upgrading options: Entering higher unit value market niches, entering new sectors, undertaking new productive functions and in all cases enlarging the technological capabilities of the firms. In general upgrading can be viewed as synonymous with positive value chain development.

\section{Demand of Dairy and Dairy Products in Ethiopia}

Higher incomes, larger urban populations and continued population growth will fuel higher demand for dairy products (Feleke, 2010 and LMD, 2013). However, consumption during the last four decades ranged from 16 to 19 liters per capita, about half of the average African consumption rates, and well below the world average. The level of consumption has only increased slightly since 2000 .

Ethiopia consumes approximately $17 \mathrm{~kg} /$ capita (LMP, 2007). Approximately $83 \%$ of the total milk produced is consumed at the household level and only $7 \%$ is supplied to the formal and informal markets. The remaining balance is distributed between inkind wages $(0.43 \%)$, and used for processing local butter, yogurt, and cheese $(10.06 \%)$ primarily as a means of extending the shelf life during times of surplus.

In urban area specially, in the Addis Ababa market, 5,000 commercial producers (estimate in 2002) sold $73 \%$ of their production, $10 \%$ went to household consumption, $9.4 \%$ to calves, and $7.6 \%$ was processed (Azage, et al., 2010). Whereas, the demand for milk in rural area is mainly for fresh whole milk, which is satisfied by own production or purchased from neighbors. Processed milk is currently not sold in rural markets. In the rural areas, producers will consume fresh milk and will convert their milk to butter. It is estimated that $40 \%$ of the milk produced is converted to butter, while only $9 \%$ is converted to cheese (Livestock Master Plan - LMP, 2007). In further pastoral milk consumption, vary according to season variation. In the wet season, milk consumed by pastoral children can account for $67 \%$ of the mean daily energy they require and $100 \%$ of their protein requirements (Sadler, 2009). Lack of availability and access to milk in the dry season decreased daily consumption amounts by almost $25 \%$ with milk contributing only $16 \%$ and $50 \%$ of energy and protein requirements respectively.

\section{RESEARCH METHODS}

Description of the Study Area: This study was undertaken in south Eastern Part of Ethiopia in potential district (namely of Oromia regional state) in dairy production. Description for the town is given below: Bishoftu is located at $45 \mathrm{~km}$ distance from Addis Ababa in South East (Figure 2). The area is located at $9^{\circ} \mathrm{N}$ latitude and $40^{\circ} \mathrm{E}$ longitude at altitude of $1850 \mathrm{~m}$ with annual rain fall of $866 \mathrm{~mm}$, of which $84 \%$ is in the long rainy season June to September. The annual average temperature ranges from $12.3 \mathrm{oC}$ to $27.7 \mathrm{oC}$ with an overall average of $18.7 \mathrm{oC}$. The soil and climate are similar to those in many highland areas in Ethiopia. It is an important town 
where most governmental institutions, national and international research centers are located. Cattle, small ruminant, poultry and equines are the major livestock species kept with fast growing small scale dairy production (NMSA, 2010).

Type and Sources of Data: This study depends on cross sectional study design in which both quantitative and qualitative type of data were used. The data were collected from primary and secondary sources.

Sampling Procedure and Sample Size: This study used census of dairy producers in the town to collect data from a total of 141 respondents. In Bishoftu town there are 100 small scale, 34 medium scale and 7 large scale dairy producers. The necessary data were collected from these three categories of producers. In addition 5 collectors, 10 retailers and 8 consumers are randomly selected.

Methods of Data Collection: questionnaire were used to collect data from dairy producers, processors and other actors who participate in dairy value chain in the town. Participatory research approach is believed as an efficient way to jointly understand value chain constraints and jointly identify value chain upgrading strategies. It is believed to generate policy relevant information that can provide guidance for development interventions and for guiding formal survey. Thus, interview with key informants and value chain actors at various levels within the town were conducted.

\section{Methods of Data Analysis}

Descriptive Analysis: Descriptive statistics were used to analyze the data. Value chain analysis approaches mapping and calculating cost and margin, and share of dairy producers used in the dairy value addition process.

\section{RESULTS AND DISCUSSIONS}

The Participation of Dairy Producers' in the Production of Dairy Products

According to the survey result $46 \%$ of dairy producers were participating in dairy processing. Among dairy processors $24 \%$ were producing yogurt, $11 \%$ of processors were producing cheese and butter and the other $11 \%$ of processors producing yogurt, cheese and butter.

Table1: Types dairy of products produced in the town by producers

\begin{tabular}{lrr}
\hline Types of produced dairy product & Frequency & Percent \\
\hline & & \\
milk/dairy & 75 & 53.6 \\
Yogurt & 34 & 24.3 \\
cheese and butter & 15 & 10.7 \\
yogurt, cheese and butter & 16 & 11.4 \\
\hline Total & 140 & 100.0 \\
\hline
\end{tabular}

\section{Actors in Dairy Value Chain and Their Role}

Value chain actors are classified as those individuals who take ownership of a product, through the exchange of money or equivalent goods or services, during the transaction process of moving the product from conception to the end user. Those individuals or firms providing a service without taking ownership of the product are classified as service providers. The direct actors are those involved in commercial activities like input suppliers, producers, traders, dairy cooperative (Adea dairy cooperative), private company (Holland and Mama dairy) and consumers. In direct actors are those who provide financial and non-financial support services such as business service providers, NGO's, and Researchers. Actors in dairy value chain upgrading and their roles in the study area are presented below.

\section{Primary Actors}

Input suppliers: for dairy value chain upgrading there were actors who are involved in dairy input supply. In Bishoftu town, there were different individuals and private companies that were sources of input supply. These were Genesis farm, Alfa alfa fodder and dairy production, Alema kaudijis plc and smallholders' farmers who sell crop residuals. Alfa alfa fodder and dairy production was private company who produce alfa alfa fodder which is used as animal feed and it also produce dairy in commercial basis. Genesis farm also known in its production of alfa alfa and raised dairy cow commercially like alfa alfa fodder and dairy farm Company which is owned by investors from the Netherlands.

\section{Dairy producers}

These are primary actors for dairy and its products (yogurt, cheese and butter) both to produce and supply to the market. Dairy producers are the main actors who perform most of the value chain function from right input supply (preparation) on their farms. The major value chain functions of dairy producers include supply feeds, producing dairy/milk, processing, postharvest handling, marketing and consumption of dairy and dairy products. Milk/dairy producers dominated by small scale producers in the town who were 100 in number. They supply dairy to neighbors, Adea cooperative, Holland dairy, Mama dairy and different hotels and restaurants. Similarly cheese and butter producers supply to consumers.

Medium scale dairy producers were growing in number in Bishoftu town. They were 34 in number. They produce dairy/milk, yogurt, cheese, and butter in commercial basis. They gave raw milk to cooperative (Adea), 
Private company (Holland dairy, Mama dairy and other hotel and restaurants), and to consumers. But, medium scale dairy producers also process dairy into its product and acts as trader of milk and milk products. There were only seven large scale dairy producers in Bishoftu town Buzuayew private dairy farm, Hora dairy farm, Elvera dairy farm, Alfa alfa and fodder dairy farm, Genesis farm, G.G.K dairy farm and Doctor Tilahun Private dairy farm. Except Alfa alfa and fodder dairy farm all large scale dairy producers were producing and processing dairy into different product. But, alfa alfa and fodder dairy which is owned by Holland investors gave milk to Holland dairy plc processing company which found in the town.

\section{Traders (Retailers)}

These were actors who collect dairy and its products from small scale dairy producers and change it into different products and then sell to consumers. They had license and collect milk from producers to sell to consumers. They also process dairy into its product. They are 5 in the town.

\section{Dairy cooperative}

There is one pillar dairy cooperative in Bishoftu town; that is Adea dairy cooperative. It was established in 1998 with 34 members with initial capital of 3400 ETB. Nowadays it has 300 members. But, active members are 100 dairy producers. This cooperative has modern complex centrifugal dairy processing machine which can process 15000 liters of milk at a time. It collects milk from its members and process in to different products. The products that it produces were pasteurized milk, yogurt, cheese, food butter, cosmotic butter and ice cream. By now its capital is about 12 billion ETB.

\section{Private company/traders}

These were actors who collect dairy product from producers and differentiate dairy into different product and distribute to supermarkets of Bishoftu and Finfine (Addis Ababa). Holland and Mama dairy were private companies who collect dairy from Bishoftu town dairy producers for processing. Holland dairy is owned by Holland investors it established for dairy processing, But Mama dairy was found in sebata town and collect milk in Bishoftu town on behave of its branch in the town. The price of dairy was determined by buyers. They bought on average by 14 ETB and sold with 18 ETB per liter.

\section{Consumers}

Consumers were those who purchase dairy products for consumption. They were the last link in dairy marketing chain. Household and individuals were major customers of dairy products. According to the study there was uneven demand because of orthodox followers fasting period on the dairy product for certain consumer. But, the supply was even and the producers who are selling their product directly to consumer suffer of this situation in the town.

\section{Supporting Actors}

These actors were those who provide services like training, extension, information, financial and research services. In addition to processing dairy, Adea dairy cooperative and Holland dairy gave training for dairy producers. There were also government's organizations that support the producers of the town such as Ethiopian meat and dairy industry institute which gives training for produces in order to build their capacity, Ethiopian research center and national veterinary institute were all found in the town.

\section{Influencing Actors}

These were actors including regulatory framework and policies town revenue authority and trade and market development office of Bishoftu town. These actors suits environment for dairy producers by investigating problems related to production, processing and marketing though formulating policies and encouraging and doing researches on sector. In Bishoftu town there were problem of land for dairy production. Bishoftu town dairy department grouped producers and provided them land for dairy production. 


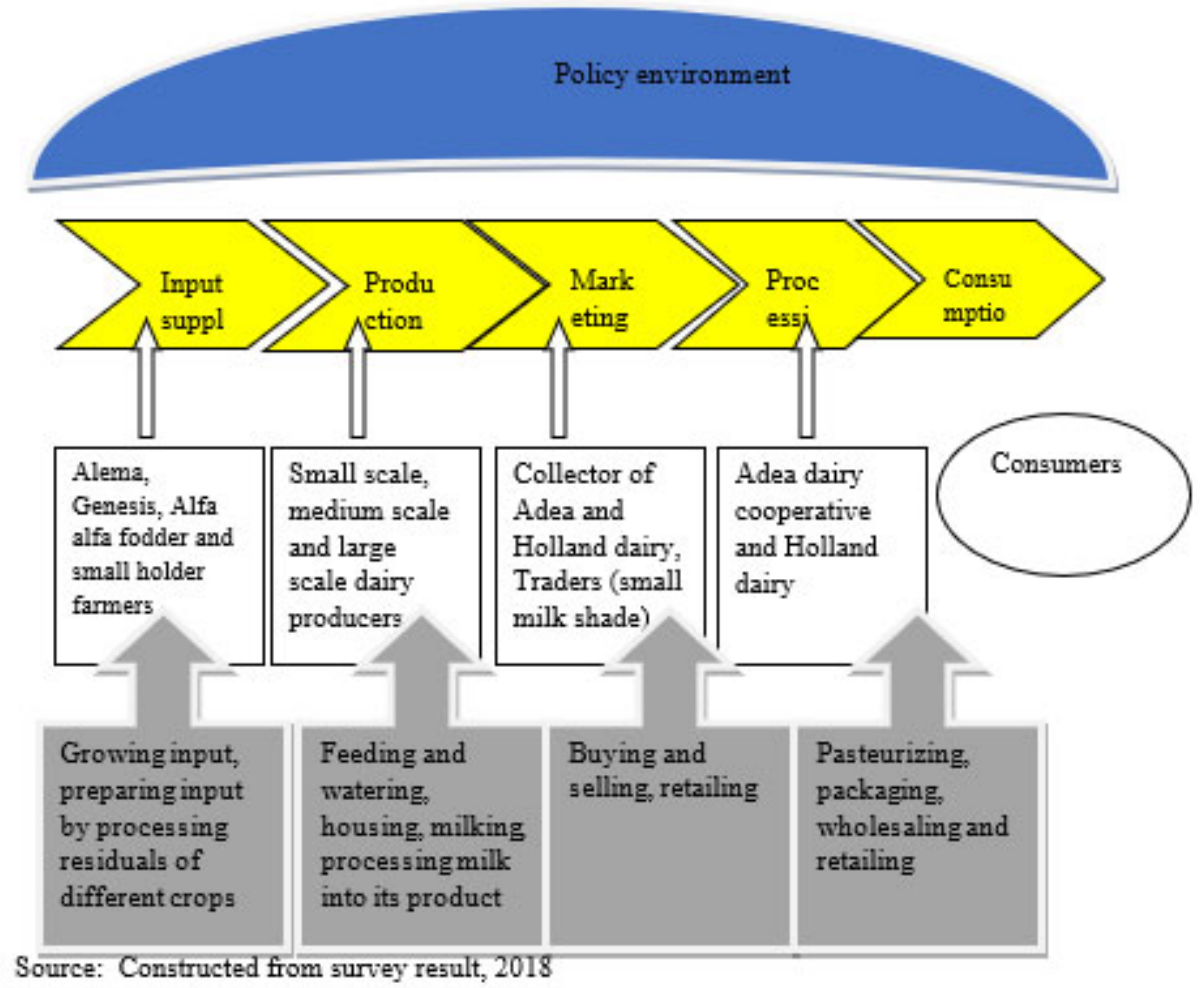

Source: Constructed from survey result, 2018

Figure1: Functions, actors and activities of actors along dairy value chains in the study areas

\section{CONCLUSION AND RECOMMENDATION}

\section{Conclusion}

Actors in dairy value chain and their role in upgrading the chain were analyzed. The data were generated from both primary and secondary sources. The primary data were collected from individual interview and structured questionnaire. The primary data for this study were collected from 140 dairy producers, 5 collectors, 10 retailers and 8 consumers. Value chain analysis is used for analysis.

\section{Recommendation}

Among dairy producers in Bishoftu town $46 \%$ were processing milk in to different product whereas $55 \%$ sold fresh milk according to the survey result. In dairy value chain small scale dairy producers were a group who sold fresh milk. Therefore, the focus needed to be given for small scale dairy producers from policy perspective and training for capacity in order to upgrade the sector.

\section{Acknowledgments}

We would like to extend our sincerest acknowledgment to all administrative leaders, sample interviewees, enumerators and other stakeholder.

\section{REFERENCES}

Azage, T., Berhanu, GM., Hoekstra, D., 2010. Livestock input supply and service provision in Ethiopia: challenges and opportunities for market-oriented development. IPMS of Ethiopian Farmers Project working paper 20ILRI, Nairobi, Kenya. 2010. 48pp.

Feleke, G., 2010. The Ethiopian Dairy Development Policy: A Draft Policy Document. Ministry of Agriculture/AFRDRD/AFRDT Food and Agricultural Organization of the United Nations/SSFF, Addis Ababa, Ethiopia.

Gereffi, G., and Luo, X., 2014. "Risks and opportunities of participation in global value chains ,Policy Research Working Paper 6847, World Bank, Washington, DC.

Girma, D., and Marco, V., 2013. Assessment of factors and factors affecting milk value chain in smallholder dairy farmers: A case study of Ada'a District, East Shawa Zone of Oromia regional State, Ethiopia

Girma, D., 2012. Production Chain Management with Specialization in Livestock Chain: A research Project submitted to the van Hall Larenste in University of applied Science in Partial fulfillment of the requirements for the Master Degree in Agricultural

Jonathan, M., Jodie, K., and Christopher, C., 2009. Trading Up: How a Value Chain Approach Can Benefit the Rural Poor 
Kaplinsky, R,. and Morris, M., 2003.Hand book for value chain research.

LDMPS (Livestock Development Master Plan Study), 2007. Phase Report - Data Collection and Analysis Volume I - Dairy. GRM International BV

McCullough, E.B., Pingali, P.L., and Stamoulis, K.G., (eds.) 2008. The Transformation of Agri- Food Systems: Globalization, Supply Chains and Smallholder Farmers. London: Earthscan and FAO.

Mohammed, L., Sardana, B., Sahay, S., Waheed, A., 2009. Supply Chain Partners ${ }^{\text {ee }}$ trust building process through risk evaluation: the perspective of UAE packaged food industry, supply chain management: An international Journal, vol 4, and no.2 pp280-290.

NMSA, 2010. National Metrological Agency of Addis Ababa, Ethiopia

Pingali, P. L., \& Timmer, C., 1997. "From Subsistence to Commercial Production Systems: The Transformation of Asian Agriculture," American Journal of Agricultural Economics 79(2): 628-634.

Porter, M., 1990. The competitive advantage of nations, Simon and Schuster.

Rich, K., Ross, R., Bekar, D., Negassa, A., 2010. Extending value chain analysis to livestoch systems in developing counties.

Sadler, K., 2009. Milk Matter: Alternative Review of pastoralists Nutrition and programming responses.

World Bank, 2008. Agriculture for Development, World Bank World Development Report 2008. Washington, DC: The World Bank. 